\title{
Dopamine D2 Receptor Gene and Alcoholism Among Four Aboriginal Groups and Han in Taiwan
}

\author{
Wei J. Chen, ${ }^{2}$ Mong-Liang Lu, ${ }^{2}$ Yun-Pung P. Hsu, ${ }^{1}$ Chiao-Chicy Chen, ${ }^{3}$ Jeng-Ming Yu, ${ }^{3}$ \\ and Andrew T.A. Cheng ${ }^{*}$ \\ ${ }^{1}$ Division of Epidemiology and Public Health, Institute of Biomedical Sciences, Academia Sinica, Taipei, Taiwan \\ ${ }^{2}$ Institute of Epidemiology, College of Public Health, National Taiwan University, Taipei, Taiwan \\ ${ }^{3}$ Department of Adult Psychiatry, Taipei City Psychiatric Center, Taipei, Taiwan
}

Previous studies examining the putative association between DRD2 TaqI A1 and alcoholism have produced conflicting results. Major critiques of such studies include potential confounding arising from population admixture by inappropriate selection of controls, failure to screen out substance abusers from controls, and the failure to assess the severity of alcoholics. To address these issues, we compared the allelic frequency of two polymorphisms of DRD2, TaqI A and NcoI, among severe alcoholics and their ethnically matched nonalcoholic controls within four major aboriginal groups and Han (Chinese) in Taiwan. The sample of alcoholics and controls examined for the five groups included 36 and 31 (Atayal), 24 and 23 (Ami), 58 and 58 (Bunun), 35 and 35 (Paiwan), and 50 and 66 (Han). A borderline association between TaqI A1 and alcoholism among the Ami $(P=0.08)$ and an association between NcoI N1 and alcoholism among Han $(P=$ 0.01 ) were found. Results of haplotype analysis further confirm that the frequency of haplotype A1N1 was higher in alcoholics than in controls for the Ami $(P=0.01)$ and Han $(P=$ $0.03)$. If controls with tobacco abuse were excluded from the analysis, the results remained unchanged. Severity in medical complications of alcohol dependence with withdrawal symptoms was not associated with higher prevalence of DRD2 TaqI A1 or NcoI $\mathrm{N} 1$ alleles. The absence of an association between DRD2 and alcoholism among the three

Contract grant sponsor: National Science Council Taipei; Contract grant numbers NSC 75, 76-0301-H002-28, NSC 78, 790301-H002-40, NSC 83-0203-B001-102, NSC 84-2331-B001-046; Contract grant sponsor: Department of Health, Taiwan; Contract grant numbers DOH-80-03, DOH-81-111.

*Correspondence to: Dr. Andrew T.A. Cheng, Division of Epidemiology and Public Health, Institute of Biomedical Sciences, Academia Sinica, Taipei, Taiwan.

Received 27 March 1996; Revised 22 July 1996 aboriginal groups suggests either a higher rate of phenocopies among aboriginal alcoholics or genetic heterogeneity in the susceptibility to alcoholism. Am. J. Med. Genet. 74:129-136, 1997. @ 1997 Wiley-Liss, Inc.

KEY WORDS: DRD2; susceptibility; restriction fragment length polymorphism; population admixture

\section{INTRODUCTION}

Evidence from previous family, twin, and adoption studies indicates that alcoholism is a complex behavior that most likely results from the interplay between genetic predisposition and environmental factors [Cloninger, 1987; Merikangas, 1990]. In the search for vulnerability genes for such a complex disorder, disease-marker association studies have become increasingly popular as an alternative to linkage analysis because of the ambiguity of the definition of phenotypes as well as mode of inheritance and the possibility of multiple gene involvement [Crowe, 1993; Hodge, 1994]. One area of intensive research has focused on an association between certain anonymous restriction fragment length polymorphisms (RFLPs) of dopamine D2 receptor gene (DRD2) and alcoholism. After Blum et al. [1990] reported that the frequency of TaqI A1 allele of DRD2 was higher in alcoholics than in nonalcoholic controls, several subsequent studies of other populations have replicated the finding [Blum et al., 1991; Comings et al., 1991; Noble et al., 1991; Parsian et al., 1991; Amadeo et al., 1993; Neiswanger et al., 1995a]. However, many failed to do so [Bolos et al., 1990; Gelernter et al., 1991; Cook et al., 1992; Goldman et al., 1992; Turner et al., 1992; Arinami et al., 1993; Suarez et al., 1994; Sander et al., 1995; Lu et al., 1996].

There are many possible explanations for the inconsistent results. Since there is a wide variation in the allelic frequency of TaqI A1 of DRD2 among different populations [Barr and Kidd, 1993], one possibility is confounding by population admixture due to unmatched 
ethnicity between cases and controls [Gelernter et al., 1993; Pato et al., 1993]. The sample size of previous studies, such as Cook et al. [1992] and Lu et al. [1996], may not have sufficient power to detect the association. Some researchers have suggested that the association may exist exclusively among severe alcoholics [Blum et al., 1991; Parsian et al., 1991; Arinami et al., 1993], and the prevalence of DRD2 A1 allele has been found to be higher in more severe alcoholics than in less severe ones [Blum et al., 1993; Noble et al., 1994]. Reports also have shown that other substance use disorders are associated with DRD2 gene [Smith et al., 1992; Noble et al., 1993, 1994]. Thus previous negative findings may be limited by the failure to select severe cases of alcoholic as well as the failure to exclude other substance abuser from controls [Blum et al., 1995]. Linkage analyses among alcoholic pedigrees of small samples have failed to detect linkage between DRD2 and alcoholism [Bolos et al., 1990; Parsian et al., 1991; Neiswanger et al., 1995a]. Thus the nature of the association between TaqI A1 of DRD2 and alcoholism remains unsettled.

The controversy over the DRD2/alcoholism has led some to question the utility of population association study in the genetic analysis of complex disorders [Crowe, 1993; Kidd, 1993; Carey, 1994]. However, a gene that is not necessary for but alters susceptibility to a disease may not be detected in linkage analysis while detectable in a population-based association study [Greenberg, 1993]. In this regard, association studies are an inexpensive and sensitive way to find correlations between biological traits and diseases of unknown etiology [Neiswanger et al., 1995b]. Thus it is still worthwhile to examine the relationship between DRD2 and alcoholism in carefully ascertained subjects among different populations. In this study, we compared the allelic frequency of two polymorphism of DRD2, TaqI A (located on 3' noncoding region) [Blum et al., 1991] and NcoI (located on exon 6) [Sarkar et al., 1991], among four major aboriginal groups and the main inhabitants, Han (Chinese), in Taiwan. Relationship between severity of medical complications of alcoholism and DRD2 gene was also examined.

\section{MATERIALS AND METHODS Subjects}

The ascertainment of subjects examined in this study has been described in detail elsewhere for the four aboriginal groups [Chen et al., 1996] and Han [Chen et al., 1996]. In brief, subjects who met the DSM-III-R [APA, 1987] criteria of alcohol dependence with withdrawal symptoms were included as cases. The controls were subjects who had no alcohol problems (either never drank or only occasionally drank in low quantity) and were matched on the basis of ethnicity and sex to cases. Older eligible subjects were preferred as matched controls to avoid misclassification in phenotype. Any subjects born from an interethnic marriage were excluded. Related subjects were also eliminated from eligibility. The alcoholic status of the subjects was assessed by a psychiatrist or well-trained research assistants with a semistructured clinical interview schedule for alcoholism. The reliability of the instrument has been reported to be satisfactory [Cheng and Chen, 1995].

The aboriginal subjects were ascertained from either a two-phase survey, Taiwan Aboriginal Study Project (TASP) [Cheng and Hsu, 1992] among four aboriginal groups (Atayal, Ami, Bunun, and Paiwan), or referred to us via local health workers. Almost all cases were identified from the community, and many of them have been treated for various complications of alcohol drinking, although few had ever been treated for alcoholism per se due to poor accessibility of psychiatric services. The Han alcoholic subjects were recruited from both community (Chinshan and Sanchi Township) and clinical settings (Taipei City Psychiatric Center and Chinshan Health Station) in northern Taiwan; the Han controls were recruited from both the community (Chinshan and Sanchi Township) and the Health Screening Ward at National Taiwan University Hospital.

In total, 203 alcoholics (168 men and 35 women) and 213 controls (178 men and 35 women) were genotyped for this study. The ratio of male and female cases for each group was as follows: 25 and 11 (Atayal), 21 and 3 (Ami), 44 and 14 (Bunun), 31 and 4 (Paiwan), and 47 and 3 (Han), while that of controls included: 19 and 12 (Atayal), 20 and 3 (Ami), 44 and 14 (Bunun), 31 and 4 (Paiwan), and 64 and 2 (Han). The mean age for each group ranged from 41.2 to 51.1 for cases and from 54.2 to 61.0 for controls. To exclude a possible confounding by tobacco abuse among controls, those who have smoked at least one pack of cigarettes per day for at least 1 year were deleted from part of the analysis.

\section{Severity of Medical Complications}

Since the alcoholics included in this study all suffered from withdrawal symptoms, we consider them all to be severe alcoholics. However, to explore further the possible relationship between the severity of medical complications and DRD2 gene, we subclassified the alcoholics as more severe if they had any one of the following complications: (1) impairment of liver function, which, because acquisition rates of chronic hepatitis $\mathrm{B}$ virus and hepatitis $\mathrm{C}$ virus infections among the general Taiwanese population can reach as high as $15-20 \%$ and $1-5 \%$, respectively, we defined as those without hepatitis $\mathrm{B}$ and $\mathrm{C}$ virus seropositivity and a combination of an alanine aminotransferase level of $>35$ IU/liter and an aspartate aminotransferase level of $>40$ IU/liter [Shen et al., 1996]; (2) peripheral neuropathy, if subjects reported that alcohol consumption produced sensations of tingling or numbness in the feet; and (3) hallucinations. These criteria were selected because they could be laboratory determined, or self-reports of high accuracy in a field survey setting. Other major medical complications but relatively rare in this sample, such as pancreatitis or delirium tremens, were found to co-exist with at least one of the above complications. Some medical diseases such as gastritis, gastrointestinal bleeding, and gout were not included as criteria for severity because the causative role of alcohol consumption in these illnesses could not be clarified in a field setting. 


\section{Genotype Determinations}

After informed consent was obtained, $30 \mathrm{ml}$ of venous blood was drawn from each participant. Ten $\mathrm{ml}$ was used for the isolation of leukocyte DNA according to the protocol of Sambrook et al. [1989] or with a commercial kit GENOMIX (Talent, Italy).

TaqI A polymorphism. According to Grandy et al. [1993], primers 971 (5'CCGTCGACGGCTGGCCAAGTTGTCTA3') and 5014 (5'CCGTCGACCCTTCCTGAGTGTCATCA3') were used to amplify a $310 \mathrm{bp}$ region near $3^{\prime}$ flanking region, close to exon 8, of DRD2. When the PCR product was incubated with TaqI, the A1 allele remained intact, whereas the $\mathrm{A} 2$ allele was cut into two pieces of 130 and $180 \mathrm{bp}$. The PCR was carried out with $100 \mathrm{ng}$ genomic DNA, $1 \mathrm{X}$ buffer $(10 \mathrm{mM} \mathrm{KCl}, 20 \mathrm{mM}$ Tris-HCl, $\mathrm{pH} 8.8$ at $25^{\circ} \mathrm{C}$, and $.01 \%$ Triton X-100), 1.5 $\mathrm{mM} \mathrm{MgCl} 2,120 \mathrm{pmol}$ of each primer, $2.5 \mathrm{mM}$ dNTPs, and 2 units of Tag polymerase in a $20 \mu \mathrm{l}$ reaction mixture. The PCR protocol was carried out at $94^{\circ} \mathrm{C}$ for 3 min, 40 cycles of $94^{\circ} \mathrm{C}$ for $1 \mathrm{~min}, 58^{\circ} \mathrm{C}$ for $1 \mathrm{~min}$, and $72^{\circ} \mathrm{C}$ for $1 \mathrm{~min}$, with a final extension of $72^{\circ} \mathrm{C}$ for $5 \mathrm{~min}$ in a GeneAmp PCR System 9600. The PCR product was precipitated with $2 \mu \mathrm{l}$ sodium acetate $(\mathrm{pH} 7.0)$ and $40 \mu \mathrm{l}$ $100 \%$ alcohol. The purified DNA was then incubated with 5 units of TaqI under the recommended conditions of the enzyme for $8 \mathrm{hr}$. The three fragments were differentiated using $4 \%$ agarose gel.

NcoI polymorphism. According to Sarkar et al. [1991], primers 35 (5'ATCCTGCAGCCATGG3') and 38 (5'ATTGTCCGGCTTTACC3') were used to amplify a $480 \mathrm{bp}$ region on exon 6 of DRD2. The polymorphism was due to a silent change (a $\mathrm{C}$ to $\mathrm{T}$ transition) at amino acid $\mathrm{His}^{313}$. When the PCR product was incubated with NcoI, the N1 allele remained intact, whereas the N2 allele was cut into two pieces of 194 and $252 \mathrm{bp}$. The reagents and temperature protocol for the PCR of NcoI was similar to that of TaqI A except that the annealing temperature was changed to $55^{\circ} \mathrm{C}$ for $1 \mathrm{~min}$. The PCR product $(20 \mu \mathrm{l})$ was incubated with 5 units of NcoI under the recommended conditions of the enzyme for $8 \mathrm{hr}$ and then was differentiated using $4 \%$ agarose gel.

\section{Statistical Analysis}

The differences in allele or genotype frequencies between cases and controls were examined by Fisher's exact test (2-tail), and the Hardy-Weinberg disequilibrium was tested by $\chi^{2}$ analysis with Yates' continuity correction [Weir, 1990]. Frequencies in the haplotype of TaqI A and NcoI were estimated by using Hill's [1974] iteration algorithm. Heterogeneity of haplotype frequencies between cases and controls was based on likelihood Chi-square test rather than Pearson Chi-square test since there were cells with small expected values. For convenience, we denoted the frequency of the rarer allele at the first locus as $\mathrm{p}$, that at the second locus as $\mathrm{q}$, and $p \leq q \leq 0.5$. The maximum likelihood estimate of linkage disequilibrium statistic $\mathrm{D}$ was computed as $\mathrm{D}^{*}=$ $f_{11}-p q$, where $f_{11}$ is the frequency of the haplotype with the rare allele at both loci. Let $n$ denote number of subjects, the statistic of the test for $D=0$ was $\left(D^{*}\right)^{2} n / p(1-$ p) $q(1-q)$, which has the $\chi^{2}$ distribution asymptotically with $1 \mathrm{df}$. The maximum possible value of $\mathrm{D}^{*}$ is $\mathrm{p}(1-$ $q$ ), denoted as $D_{\max }$, and the percentage of $D_{\max }$ achieved by $\mathrm{D}^{*}$ is $\mathrm{D}^{\prime}=\mathrm{D}^{*} / \mathrm{D}_{\max }$ [Hartl and Clark, 1989]. All statistical tests did not adjust for multiple comparisons since the association between DRD2 and alcoholism has been reported before.

\section{RESULTS}

The genotypic frequencies of TaqI A among cases and controls did not deviate from Hardy-Weinberg equilibrium for all five groups. The genotypic frequencies of NcoI deviated from Hardy-Weinberg equilibrium among cases $\left(\chi^{2}=7.83, P<.01\right)$ but not among controls for the Paiwan. The genotypic frequencies of NcoI among the cases and controls of the other four groups did not deviate from Hardy-Weinberg equilibrium.

No significant differences were found between the alcoholics and nonalcoholic controls in the genotypic frequencies, allelic frequency, and prevalence of TaqI A1 for all five groups (Table I). The frequency of A1 among controls ranged from $24-58 \%$. In contrast, the allelic frequency and prevalence of NcoI N1 among the alcoholics were significantly higher than that among the controls for Hans (Table II). No difference between cases and controls in the allelic frequency and prevalence of NcoI N1 was found for the remaining four groups. The allelic frequency of N1 among controls ranged from $32-55 \%$.

If controls who have had tobacco abuse (one Atayal, one Ami, seven Bunun, two Paiwan, and 15 Han) are excluded from the analysis, the prevalence of TaqI A1 allele for the five control groups was .77 (Atayal), .41 (Ami), .65 (Bunun), .64 (Paiwan), and .67 (Han), which were similar to those of the original controls. There were no differences in the prevalence of TaqI A1 between the tobaccoabuse free controls and alcoholics for all five groups. The prevalence of NcoI N1 allele for the five tobacco-abuse free control groups was .73 (Atayal), .59 (Ami), .57 (Bunun), .85 (Paiwan), and .59 (Han). For Hans, the prevalence of NcoI N1 among the alcoholics were still significantly higher than that among the tobacco-abuse free controls $(P=0.03)$. No difference between cases and tobacco abuse-free controls in the prevalence of NcoI N1 was found for the remaining four groups. The results of comparing the genotypic frequencies and allelic frequencies of TaqI A and NcoI between cases and tobacco-abuse free controls were similar to those of prevalence of TaqI A1 and NcoI N1 (data not shown).

Since TaqI A and NcoI are closely linked around the DRD2 gene, we examined the haplotypes and degree of linkage disequilibrium between the two loci in the sample (Table III). The haplotypes of TaqI A and NcoI sites were significantly associated with alcoholism for the Ami and Han. Alcoholics of the two groups had a higher frequency of $\mathrm{A} 1 \mathrm{~N} 1$ than that of the controls. The degree of linkage disequilibrium, $\mathrm{D}^{*}$, among cases and controls for all five groups were significantly different from zero. All the percentages of maximum linkage disequilibrium achieved by $\mathrm{D}^{*}, \mathrm{D}^{\prime}$, were $\geq 60 \%$. Notably, the $\mathrm{D}^{\prime}$ of cases was significantly higher than that of controls for the Paiwan $(\mathrm{z}=4.3, P<0.001)$ and Hans $(\mathrm{z}=3.4$, $P<0.001$ ). The $\mathrm{D}^{\prime}$ of cases was not significantly different from that of controls for the Atayal, Ami, and Bunun. 
TABLE I. Genotype Distributions, Allele Frequencies, and Prevalence of DRD2 TaqI A Polymorphism Among Taiwanese Aborigines and Han

\begin{tabular}{|c|c|c|c|c|c|c|c|c|c|}
\hline \multirow{2}{*}{$\begin{array}{l}\text { Group and } \\
\text { status }\end{array}$} & \multirow[b]{2}{*}{$\mathrm{n}$} & \multicolumn{4}{|c|}{ Genotype, n (frequency) } & \multicolumn{2}{|c|}{ Allele frequency } & \multicolumn{2}{|c|}{ Prevalence } \\
\hline & & A1A1 & $\mathrm{A} 1 \mathrm{~A} 2$ & $\mathrm{~A} 2 \mathrm{~A} 2$ & $\operatorname{FET}(p)^{*}$ & A1 & $\operatorname{FET}(\mathrm{p})^{*}$ & A1 & $\operatorname{FET}(p)^{*}$ \\
\hline \multicolumn{10}{|l|}{ Atayal } \\
\hline Controls & 31 & $12(.39)$ & $12(.39)$ & $7(.23)$ & & .58 & & .77 & \\
\hline Alcoholics & 36 & $9(.25)$ & $18(.50)$ & $9(.25)$ & .49 & .50 & .39 & .75 & 1.00 \\
\hline \multicolumn{10}{|l|}{ Ami } \\
\hline Controls & 23 & $2(.09)$ & $7(.30)$ & $14(.61)$ & & .24 & & .39 & \\
\hline Alcoholics & 24 & $4(.17)$ & $12(.50)$ & $8(.33)$ & .17 & .42 & .08 & .67 & .08 \\
\hline \multicolumn{10}{|l|}{ Bunun } \\
\hline Controls & 58 & $6(.10)$ & $29(.50)$ & $23(.40)$ & & .35 & & .60 & \\
\hline Alcoholics & 58 & $3(.05)$ & $32(.55)$ & $23(.40)$ & .61 & .35 & .78 & .60 & 1.00 \\
\hline \multicolumn{10}{|l|}{ Paiwan } \\
\hline Controls & 35 & $4(.11)$ & $18(.51)$ & $13(.37)$ & & .37 & & .63 & \\
\hline Alcoholics & 35 & $2(.05)$ & $22(.63)$ & $11(.31)$ & .55 & .37 & 1.00 & .69 & .80 \\
\hline \multicolumn{10}{|l|}{ Han } \\
\hline Controls & 66 & $6(.09)$ & $37(.56)$ & $23(.35)$ & & .37 & & .65 & \\
\hline Alcoholics & 50 & $10(.20)$ & $26(.52)$ & $14(.28)$ & .24 & .46 & .18 & .72 & .55 \\
\hline
\end{tabular}

* $P$ value of Fisher's exact test.

If the alcoholics were subclassified according to the severity of medical complications, the proportion of more severe alcoholics ranged from 53\% (Atayal) to $71 \%$ (Bunun) (Table IV). The prevalences of TaqI A1 and NcoI N1 alleles for the more severe alcoholics were not significantly higher than those for the less severe alcoholics. The trend was even reversed in the Han, although not to a statistically significant level. There were also no differences in the genotypic and allelic frequencies of TaqI A and NcoI between more severe alcoholics and less severe ones.

\section{DISCUSSION}

The subjects examined in this study belong to five different ethnic groups. The prevalence of alcoholism was much higher among the four aboriginal groups than among Han in Taiwan (Cheng and Chen, 1995). Thus we did not pool all subjects together. Several methodological issues that have been raised in the controversy about the DRD2 and alcoholism warrant discussion before examining the results.

One critical issue is the selection of controls. In this study, the aboriginal controls were selected from the same community as cases and their ethnicity strictly matched. The Han controls were selected from either the same community or catchment area of a hospital as cases and their ethnicity was also matched. This would make the relationship between DRD2 and alcoholism confounded by population admixture less likely for this study. As noted by Gelenrter et al. [1991] and Neiswanger et al. [1995b], there is a difference in allelic frequency of TaqI A1 between unscreened and screened

TABLE II. Genotype Distributions, Allele Frequencies, and Prevalence of DRD2 NcoI Polymorphism Among Taiwanese Aborigines and Han

\begin{tabular}{|c|c|c|c|c|c|c|c|c|c|}
\hline \multirow{2}{*}{$\begin{array}{l}\text { Group and } \\
\text { status }\end{array}$} & \multirow[b]{2}{*}{$\mathrm{n}$} & \multicolumn{4}{|c|}{ Genotype, n (frequency) } & \multicolumn{2}{|c|}{ Allele frequency } & \multicolumn{2}{|c|}{ Prevalence } \\
\hline & & N1N1 & N1N2 & N2N2 & $\operatorname{FET}(\mathrm{p})^{*}$ & N1 & $\operatorname{FET}(p)^{*}$ & $\mathrm{~N} 1$ & $\operatorname{FET}(\mathrm{p})^{*}$ \\
\hline \multicolumn{10}{|l|}{ Atayal } \\
\hline Controls & 31 & $11(.35)$ & $12(.39)$ & $8(.26)$ & & .55 & & .74 & \\
\hline Alcoholics & 36 & $9(.25)$ & $20(.56)$ & $7(.19)$ & .39 & .53 & .86 & .81 & .57 \\
\hline \multicolumn{10}{|l|}{$\mathrm{Ami}$} \\
\hline Controls & 23 & $3(.13)$ & $10(.43)$ & $10(.43)$ & & .35 & & .57 & \\
\hline Alcoholics & 24 & $4(.17)$ & $12(.50)$ & $8(.33)$ & .79 & .42 & .53 & .67 & .56 \\
\hline \multicolumn{10}{|l|}{ Bunun } \\
\hline Controls & 58 & $7(.12)$ & $23(.40)$ & $28(.48)$ & & .32 & & .52 & \\
\hline Alcoholics & 58 & $2(.03)$ & $29(.50)$ & $27(.47)$ & .19 & .28 & .67 & .53 & 1.00 \\
\hline \multicolumn{10}{|l|}{ Paiwan } \\
\hline Controls & 35 & $7(.20)$ & $23(.66)$ & $5(.14)$ & & .53 & & .86 & \\
\hline Alcoholics & 35 & $7(.20)$ & $26(.74)$ & $2(.05)$ & .64 & .57 & .73 & .94 & .43 \\
\hline \multicolumn{10}{|l|}{ Han } \\
\hline Controls & 66 & $7(.11)$ & $31(.50)$ & $28(.42)$ & & .34 & & .58 & \\
\hline Alcoholics & 50 & $11(.22)$ & $29(.58)$ & $10(.20)$ & .02 & .51 & .01 & .80 & .02 \\
\hline
\end{tabular}

$* P$ value of Fisher's exact test; $P$ values $<.05$ are in boldface. 
TABLE III. DRD2 Haplotype Frequencies and Linkage Disequilibrium for the TaqI A and NcoI Polymorphisms Among Taiwanese Aborigines and Han

\begin{tabular}{|c|c|c|c|c|c|c|c|c|}
\hline \multirow{2}{*}{$\begin{array}{l}\text { Group and } \\
\text { status }\end{array}$} & \multirow[b]{2}{*}{$2 n^{a}$} & \multicolumn{5}{|c|}{ Haplotype } & \multicolumn{2}{|c|}{$\begin{array}{c}\text { Linkage } \\
\text { disequilibrium }\end{array}$} \\
\hline & & $\mathrm{A} 1 \mathrm{~N} 1$ & $\mathrm{~A} 1 \mathrm{~N} 2$ & $\mathrm{~A} 2 \mathrm{~N} 1$ & $\mathrm{~A} 2 \mathrm{~N} 2$ & $\operatorname{LR}_{\chi}^{2}(p)^{*}$ & $\mathrm{D}^{*}$ & $\mathrm{D}^{\prime}$ \\
\hline \multicolumn{9}{|l|}{ Atayal } \\
\hline Controls & 62 & .55 & .03 & .01 & .41 & & .23 & .88 \\
\hline Alcoholics & 72 & .47 & .03 & .06 & .44 & .42 & .21 & .87 \\
\hline \multicolumn{9}{|l|}{ Ami } \\
\hline Controls & 46 & .24 & .00 & .11 & .65 & & .16 & 1.00 \\
\hline Alcoholics & 48 & .42 & .00 & .00 & .58 & .01 & .24 & 1.00 \\
\hline \multicolumn{9}{|l|}{ Bunun } \\
\hline Controls & 116 & .29 & .06 & .03 & .62 & & .18 & .74 \\
\hline Alcoholics & 116 & .23 & .10 & .05 & .62 & .47 & .14 & .60 \\
\hline \multicolumn{9}{|l|}{ Paiwan } \\
\hline Controls & 70 & .31 & .06 & .22 & .41 & & .11 & .65 \\
\hline Alcoholics & 70 & .37 & .00 & .20 & .43 & .09 & .16 & 1.00 \\
\hline \multicolumn{9}{|l|}{ Han } \\
\hline Controls & 132 & .29 & .08 & .05 & .58 & & .16 & .67 \\
\hline Alcoholics & 100 & .44 & .02 & .07 & .47 & .03 & .20 & .91 \\
\hline
\end{tabular}

controls in Caucasians. In this study, the controls have been screened to rule out subjects with heavy alcohol consumption or alcohol use disorders using the same clinical interview for the cases. Furthermore, controls with tobacco abuse were excluded from part of the analysis and the results remained the same as those of the original controls.

Several studies have indicated that the DRD2 TaqI A1 is associated exclusively with severe alcoholism. However, the criteria used to assess the severity of alcoholism were not consistent. These included medical complications [Blum et al., 1991, 1995; Parsian et al., 1991], MAST scores [Bolos et al., 1990], and withdrawal symptoms [Gelernter et al., 1991]. Turner et al. [1992] considered their sample severely affected on the basis of a high prevalence of alcohol-related automobile acci- dents, medical complications, and withdrawal symptoms. In this study, $53-71 \%$ of the alcoholics were classified as more severe by the presence of liver function impairment, peripheral neuropathy, or hallucinations. However, we did not find any significant difference in the prevalence of TaqI A1 or NcoI N1 alleles between the more severe and the less severe alcoholics. One explanation is that physical dependence on alcoholism is the essential element of severity that manifests association with DRD2 gene, whereas other medical complications arose as consequences of such addictive behaviors. Since all cases in this study fulfill this requirement, further subclassification by medical complications did not differentiate between the two subgroups in the DRD2 gene. Previous studies have indicated that addictive behavior may be closely related to the pro-

TABLE IV. Prevalence of DRD2 TaqI A1 and NcoI N1 Alleles by Severity of Medical Complications of Alcoholism Among Taiwanese Aborigines and Han

\begin{tabular}{|c|c|c|c|c|c|}
\hline \multirow{2}{*}{$\begin{array}{l}\text { Group and severity } \\
\text { in alcoholism }\end{array}$} & \multirow[b]{2}{*}{$\mathrm{N}(\%)$} & \multicolumn{2}{|c|}{ TaqI A } & \multicolumn{2}{|c|}{ NcoI } \\
\hline & & A1 & $\operatorname{FET}(p)^{*}$ & N1 & $\operatorname{FET}(p)^{*}$ \\
\hline \multicolumn{6}{|l|}{ Atayal } \\
\hline Less severe & $17(47)$ & .76 & & .71 & \\
\hline More severe & $19(53)$ & .74 & 1.00 & .89 & .22 \\
\hline \multicolumn{6}{|l|}{ Ami } \\
\hline Less severe & $9(37)$ & .67 & & .67 & \\
\hline More severe & $15(63)$ & .67 & 1.00 & .67 & 1.00 \\
\hline \multicolumn{6}{|l|}{ Bunun } \\
\hline Less severe & $17(29)$ & .59 & & .47 & \\
\hline More severe & $41(71)$ & .61 & 1.00 & .56 & .57 \\
\hline \multicolumn{6}{|l|}{ Paiwan } \\
\hline Less severe & $16(46)$ & .63 & & .94 & \\
\hline More severe & $19(54)$ & .74 & .72 & .95 & 1.00 \\
\hline \multicolumn{6}{|l|}{ Han } \\
\hline Less severe & $18(36)$ & .83 & & .89 & \\
\hline More severe & $32(64)$ & .66 & .21 & .75 & .30 \\
\hline
\end{tabular}

* $P$ value of Fisher's exact test. 
posed mechanism of the involvement of dopamine system in drug dependence [Koob and Bloom, 1988]. Further investigation with alcoholics who have medical complications due to alcohol consumption without physical dependence may help to clarify this issue.

For the four aboriginal groups examined in this study, except the borderline association between TaqI A1 and alcoholism among the Ami, neither TaqI A nor NcoI N1 of DRD2 were found to be associated with alcoholism. In contrast, an association between NcoI $\mathrm{N} 1$ and alcoholism was found among Han, whereas no similar association was found for the TaqI A1. The results of the haplotype analysis, which in general has more power in demonstrating an association between a haplotype and a disease than individually examining each marker with a disease, further confirmed that the frequency of haplotype A1N1 was higher in alcoholics than in controls for the Ami and Han. Thus our results support the reported association between DRD2 gene and alcoholism in the Ami and Han but not in the other three groups.

The greater linkage disequilibrium (larger value of $\mathrm{D}^{*}$ or $\mathrm{D}^{\prime}$ ) for the haplotype of TaqI A and NcoI among cases than among controls further supports the contention that susceptibility genes for alcoholism may be located in this area [Suarez et al., 1994]. Intriguingly, an association with polysubstance abuse was found to be stronger for TaqI B, a RFLP located at the first intron and close to exon 2, than for TaqI A [Smith et al., 1992]. However, another study found that the TaqI A1 allele is a better predictor of severe alcoholism than the B1 allele [Blum et al., 1993]. By examining four DRD2 RFLPs that span coding regions as well as a $3^{\prime}$ flanking RFLP in an enlarged sample, in which an association between TaqI A1 and alcoholism was previously found [Parsian et al., 1991], Suarez et al. [1994] found no evidence for the involvement of the DRD2 region in the vulnerability to alcoholism. In this study, both $3^{\prime}$ (NcoI) and 5' (TaqI A) of the DRD2 were indicated by the association found for the Ami and Han. Thus, although there is some evidence indicating that the region of DRD2 involved in the susceptibility to alcoholism is more likely to be in DRD2 protein coding and $5^{\prime}$ regulatory region, the data so far are still inconclusive.

A positive linkage between DRD2 and alcoholism would provide direct evidence for the involvement of DRD2 in the etiology of alcoholism. Although previous efforts failed to detect any evidence of linkage between DRD2 and alcoholism [Bolos et al., 1990; Parsian et al., 1991; Neiswanger et al., 1995a], the results of these linkage studies are clouded by the limited size of pedigrees and the uncertainty in the mode of inheritance and the definition of phenotype used. Furthermore, even if there is no detectable linkage between DRD2 and alcoholism, there still exists the possibility that DRD2 may be a susceptibility rather than a necessary gene to alcoholism [Greenberg, 1993].

Interpretation of the association between DRD2 and alcoholism, however, is complicated by the lack of functional variation related with the polymorphism of DRD2 examined in this study. The NcoI polymorphism is a silent change (a $\mathrm{C}$ to $\mathrm{T}$ transition) at amino acid $\mathrm{His}^{313}$ on exon 6 [Sarkar et al., 1991]. The TaqI A polymorphism is located on $3^{\prime}$ flanking region and $13 \mathrm{~Kb}$ to exon 8 , not in coding region. Although DRD2 receptor density was found to be less for subjects homozygous for A1 of TaqI A, followed by A1A2 and A2A2 [Noble et al., 1991], no mutations associated with alcoholism were detected in the scanning of protein-coding nucleotide sequences and splicing sites of the DRD2 gene, from exon 2-8 by denaturing gradient gel electrophoresis, among 161 alcoholics [Gejman et al., 1994]. Nevertheless we cannot rule out the possibility that the genetic defect is located in a genomic region that has not been examined, i.e., exon 1, introns, promotor or more upstream regions.

Since the possibility of confounding by population admixture is relatively low for this study, there are two possibilities for the absence of the association between DRD2 gene and alcoholism for the three aboriginal groups (Atayal, Bunun, and Paiwan). Forty years ago, the prevalence of alcoholism among the aborigines was only $0.11 \%$ [Rin and Lin, 1962]. However, subsequently the prevalence of alcohol dependence among the four aboriginal groups increased to $17.1 \%$ (Ami), $21.5 \%$ (Atayal), 23.3\% (Paiwan), and 32.0\% (Bunun), according to DSM-III-R criteria [Cheng and Chen, 1995]. It is likely that a relatively higher proportion of aboriginal alcoholics recruited for this study are in fact "phenocopies." These subjects do not carry the genetic susceptibility but become alcoholic under the tremendous psychosocial stress they have experienced during the rapid modernization process throughout these decades. Intriguingly, among the four aboriginal groups studied, Ami is the group most acculturated to the Han culture [Cheng and $\mathrm{Hsu}, 1995]$. This is in accordance with the finding that their prevalence of alcohol dependence is the lowest among the four groups. Thus the proportion of alcoholic phenocopies included in this study was relatively low in the Ami compared to the other three aboriginal groups. This may explain why the Ami is the only group of the aborigines studied that demonstrated an association between DRD2 gene and alcoholism. The other possibility is ethnic heterogeneity in the genetic susceptibility to alcoholism. We have demonstrated that the effects of certain alcohol-metabolizing genes on the risk of alcoholism are present among Han [Chen et al., 1996a] but absent among the four aboriginal groups [Chen et al., 1996b] by examining the same subjects in this study.

\section{ACKNOWLEDGMENTS}

This work was supported by grants from the National Science Council, Taipei (NSC 75,76-0301-H00228, NSC 78,79-0301-H002-40, NSC 83-0203-B001-102, NSC 84-2331-B001-046) and a grant from the Department of Health, Taiwan, ROC (DOH-80-03; DOH-81111). The authors acknowledge the hard work and excellent performance of our research assistants, Misses J.C. Chang, C.L. Cheng, J.Y. Kao, H.T. Hsu, and Y.C. Chur, and local public health workers in the fieldwork. The authors also thank Drs. K.S.Yan, T.K. Hsieh, and W.J. Chyuan for their help in the referral of aboriginal alcoholic patients and the staff at Chinshan 
Health Station and Health Screening Ward at NTU Hospital for their assistance in coordinating the recruitment of Han subjects.

\section{REFERENCES}

Amadeo S, Abbar M, Fourcade ML, Waksman G, Leroux MG, Madec A, Selin M, Champiat J, Brethome A, Leclaire Y, Castelnau D, Venisse J (1993): D2 dopamine receptor gene and alcoholism. J Psychiatr Res 27:173-179.

American Psychiatric Association (APA) (1987): "Diagnostic and Statistical Manual of Mental Disorders." 3rd rev ed. Washington, DC: APA.

Arinami T, Itokawa M, Komiyama T, Mitsushio H, Mori H, Mifune H, Hamaguchi H, Toru M (1993): Association between severity of alcoholism and the A1 allele of the dopamine D2 receptor gene TaqI A RFLP in Japanese. Biol Psychiatry 33:108-114.

Barr CL, Kidd KK (1993): Population frequencies of the A1 allele at the dopamine D2 receptor locus. Biol Psychiatry 34:204-209.

Blum K, Noble EP, Sheridan PJ, Finley O, Montgomery A, Ritchie T, Ozkaragoz T, Fitch RJ, Sadlack F, Sheffield D, Dahlmann T, Halbardier S, Nogami H (1991): Association of the A1 allele of the D2 dopamine receptor gene with severe alcoholism. Alcohol 8:409-416.

Blum K, Noble EP, Sheridan PJ, Montgomery A, Ritchie T, Jagadeeswaran P, Nogami H, Briggs AH, Cohn JB (1990): Allelic association of human dopamine D2 receptor gene in alcoholism. JAMA 263:2055-2060.

Blum K, Noble EP, Sheridan PJ, Montgomery A, Ritchie T, Ozkaragoz T, Fitch RJ, Wood R, Finley O, Sadlack AF (1993): Genetic predisposition in alcoholism: Association of the D2 dopamine receptor TaqI B1 RFLP with severe alcoholics. Alcohol 10:59-67.

Blum K, Sheridan PJ, Wood RC, Braverman ER, Chen TJ, Comings DE (1995): Dopamine D2 receptor gene variants: association and linkage studies in impulsive-additive-compulsive behavior. Pharmacogenet 5:121-141.

Bolos AM, Dean M, Lucas-Derse S, Ramsburg M, Brown GL, Goldman D (1990): Population and pedigree studies reveal a lack of association between the dopamine D2 receptor gene and alcoholism. JAMA 264:3156-3160.

Carey G (1994): Genetic association study in psychiatry: Analytical evaluation and a recommendation. Am J Med Genet (Neuropsychiatr Genet) 54:311-317.

Chen WJ, Loh EW, Hsu, Y-PP, Chen C-C, Yu J-M, Cheng ATA (1996a): Alcohol-metabolizing genes and alcoholism among Taiwanese Han Men: Independent effect of ADH2, ADH3, and ALDH2. Br J Psychiatry 168:762-767.

Chen WJ, Loh EW, Hsu Y-PP, Cheng ATA (1996b): Alcohol dehydrogenase $(\mathrm{ADH})$ and aldehyde dehydrogenase $(\mathrm{ALDH})$ genotypes and alcoholism among Taiwanese aborigines. Biol Psychiatry (in press).

Cheng TA, Chen WJ (1995): Alcoholism among four aboriginal groups in Taiwan: High prevalences and their implications. Alcohol Clin Exp Res 19:81-91.

Cheng TA, Hsu M (1992): A community study of mental disorders among four aboriginal groups in Taiwan. Psychol Med 22:255-263.

Cheng TA, Hsu M (1995): Development of an instrument for measuring acculturation: The Taiwan Aboriginal Acculturation Scale (TAAS). Psychol Med 25:1281-1287.

Cloninger CR (1987): Neurogenetic adaptive mechanisms in alcoholism. Science 236:410-416.

Comings DE, Comings BG, Muhleman D, Dietz G, Shahbahrami B, Tast D, Knell E, Kocsis P, Baumgarten R, Kovacs BW, Levy DL, Smith M, Borison RL, Evans DD, Klein DN, MacMurray J, Tosk JM, Sverd J, Gysin R, Flanagan SD (1991): The dopamine $\mathrm{D}_{2}$ receptor locus as a modifying gene in neuropsychiatric disorders. JAMA 266:1793-1800.

Cook BL, Wang ZW, Crowe RR, Hauser R, Freimer M (1992): Alcoholism and the D2 receptor gene. Alcohol Clin Exp Res 16:806-809.

Crowe RR (1993): Candidate genes in psychiatry: An epidemiological perspective. Am J Med Genet (Neuropsychiatr Genet) 48:74-77.

Gejman PV, Ram A, Gelernter J, Friedman E, Cao Q, Pickar D, Blum K, Noble EP, Kranzler HR, O'Malley S, Hamer H, Whitsitt F, Rao P, DeLisi LE, Virkkunen M, Linnoila M, Goldman D, Gershon ES
(1994): No structural mutation in the dopamine D2 receptor gene in alcoholism or schizophrenia. JAMA 271:204-208.

Gelernter J, Goldman D, Risch N (1993): The A1 allele at the D2 dopamine receptor gene and alcoholism: A reappraisal. JAMA 269: 1673-1677.

Gelernter J, O’Malley S, Risch N, Kranzler HR, Krystal J, Merikangas K, Kennedy JL, Kidd KK (1991): No association between an allele at the D2 dopamine receptor gene (DRD2) and alcoholism. JAMA 266:1801-1807.

Goldman D, Dean M, Brown GL, Bolos AM, Tokola R, Virkkunen M, Linnolia M (1992): D2 dopamine receptor genotype and cerebrospinal fluid homovanillic acid, 5-hydroxyindoleacetic acid and 3-methoxy-4-hydroxyphenylglycol in alcoholics in Finland and the United States. Acta Psychiatr Scand 86:351-357.

Grandy DK, Zhang Y, Civelli O (1993): PCR detection of the TaqA RFLP at the DRD2 Iocus. Human Mol Genet 2:2197.

Greenberg DA (1993): Linkage analysis of "necessary" disease loci versus "susceptibility” loci. Am J Hum Genet 52:135-143.

Hartl DL, Clark AG (1989): "Principles of Population Genetics," 2nd ed. Sunderland, MA: Sinauer, pp. 45-53.

Hill WG (1974): Estimation of linkage disequilibrium in randomly mating populations. Heredity 33:229-239.

Hodge SE (1994): What association analysis can and cannot tell us about the genetics of complex disease. Am J Med Genet (Neuropsychiatr Genet) 54:318-323.

Kidd KK (1993): Association of disease with genetic markers: Déjà vu all over again. Am J Med Genet (Neuropsychiatr Genet) 48:71-73.

Koob GF, Bloom FE (1988): Cellular and molecular mechanisms of drug dependence. Science 242:715-723.

Lu R-B, Ko H-C, Chang F-M, Castiglione CM, Schoolfield G, Pakstis AJ, Kidd JR, Kidd KK (1996): No association between alcoholism and multiple polymorphisms at the dopamine D2 receptor gene (DRD2) in three distinct Taiwanese populations. Biol Psychiatry 39:419-429.

Merikangas KR (1990): The genetic epidemiology of alcoholism. Psychol Med 20:11-22.

Neiswanger K, Hill SY, Kaplan BB (1995a): Association and linkage studies of the TaqI A1 allele at the dopamine D2 receptor gene in samples of female and male alcoholics. Am J Med Genet (Neuropsychiatr Genet) 60:267-271.

Neiswanger K, Kaplan BB, Hill SY (1995b): What can the DRD2/alcoholism story teach us about association studies in psychiatric genetics? Am J Med Genet (Neuropsychiatr Genet) 60:272-275.

Noble EP, Blum K, Ritchie T, Montgomery A, Sheridan PJ (1991): Allelic association of the D2 dopamine receptor gene with receptorbinding characteristics in alcoholism. Arch Gen Psychiatry 48: 648-654.

Noble EP, Blum K, Khalsa ME, Ritchie T, Montgomery A, Wood RC, Fitch RJ, Ozkaragoz T, Sheridan PJ, Anglin MD, Paredes A, Treiman LJ, Sparkes RS (1993): Allelic association of the D2 dopamine receptor gene with cocaine dependence. Drug Alcohol Dependence 33:271-285.

Noble EP, Syndulko K, Fitch RJ, Ritchie T, Bohlman MC, Guth P, Sheridan PJ, Montgomery A, Heinzmann C, Sparkes RS (1994): D2 dopamine receptor TaqI A alleles in medically ill alcoholic and nonalcoholic patients. Alcohol and Alcoholism 29:729-744.

Parsian A, Todd RD, Devor EJ, O'Malley KL, Suarez BK, Reich T, Cloninger R (1991): Alcoholism and alleles of the human D2 dopamine receptor locus: Studies of association and linkage. Arch Gen Psychiatry 48:655-663.

Pato CN, Macciardi F, Pato MT, Verga M, Kennedy JL (1993): Review of the putative association of dopamine D2 receptor and alcoholism. Am J Med Genet (Neuropsychiatr Genet) 48:78-82.

Sambrook J, Fritsch EF, Maniatis T (1989): "Molecular Cloning: A Laboratory Manual," 2nd ed. Cold Spring Harbor, NY: Cold Spring Harbor Laboratory Press, pp. E.3-E.4.

Sander T, Harms H, Podschus J, Finckh U, Nickel B, Rolfs A, Rommelspacher H, Schmidt LG'(1995): Dopamine D1, D2 and D3 receptor genes in alcohol dependence. Psychiatr Genet 5:171-176.

Sarkar G, Kapelner S, Grandy DK, Marchionni M, Civelli O, Sobell JL, Heston LL, Sommer SS (1991): Direct sequencing of the dopamine D2 receptor (DRD2) in schizophrenics reveals three polymorphisms but no structural change in the receptor. Genomics 11:8-14. 
136

\section{Chen et al.}

Shen C-Y, Lee H-S, Huang L-C, Tsai K-S, Chen D-S, Cheng ATA (1996): Alcoholism, hepatitis B and C viral infections, and impaired liver function among Taiwanese aboriginal groups. Am J Epidemiol 143:936-942.

Smith SS, O'Hara BF, Persico AM, Gorelick DA, Newlin DB, Vlahov D, Solomon L, Pickens R, Uhl GR (1992): Genetic vulnerability to drug abuse: The D2 dopamine receptor Taq IB1 restriction fragment length polymorphism appears more frequently in polysubstance abusers. Arch Gen Psychiatry 49:723-727.
Suarez BK, Parsian A, Hampe CL, Todd RD, Reich T, Cloninger CR (1994): Linkage disequilibria at the D2 dopamine receptor locus (DRD2) in alcoholics and controls. Genomics 19:12-20.

Turner E, Ewing J, Shilling P, Smith TL, Irwin M, Schuckit M, Kelsoe JR (1992): Lack of association between an RFLP near the D2 dopamine receptor gene and severe alcoholism. Biol Psychiatry $31: 285-290$.

Weir BS (1990): “Genetic Data Analysis.” Sunderland, MA: Sinauer, pp. 75-76. 